\title{
UTJECAJ E-KOMUNIKACIJE NA PODIZANJE RAZINE UČINKOVITOSTI TURISTIČKE DESTINACIJE GRADA ZAGREBA
}

Svrha je rada utvrditi važnost pristupa $i$ zastupljenosti informacijskih i komunikacijskih medija za turiste na turističkoj destinaciji Zagreb te prevladava li i u kolikoj mjeri takva vrsta komunikacije u odnosu na neposrednu komunikaciju s nositeljima turističke ponude i građanima. Sastavni dio rada čini provedeno kvantitativno istraživanje putem anketnog upitnika među turistima na turističkoj destinaciji Zagreb u razdoblju od rujna 2017. do veljače 2018. godine. U istraživanje su uključeni turisti koji su boravili u svim gradskim četvrtima turističke destinacije grada Zagreba, a popunjena su 202 anketna upitnika, od čega je 188 pravilno popunjenih. Ispitanici su, među ostalim, ocjenjivali informiranost o postojećim sadržajima destinacije, mogućnosti komuniciranja na destinaciji te važnost $i$ zastupljenost informacijskokomunikacijskog medija. Rezultati deskriptivne statističke analize pokazali su da turisti pozitivno ocjenjuju informiranost i mogućnosti komuniciranja na destinaciji s nositeljima ponude, no u ocjeni važnosti informativno-komunikacijskog medija najvažnija je dostupnost Interneta u smještajnim kapacitetima, restoranima i drugim ugostiteljskim objektima za prehranu, kao i u kaficima $i$ drugim ugostiteljskim objektima. Rezultati istraživanja ukazali su na dodatna promišljanja u definiranju mogućnosti koje u komunikaciji nudi određena destinacija i uvođenja inovacija u postojeći komunikacijski sustav.

Ključne riječi: e-komunikacija, turistička destinacija, društvene mreže, digitalizacija

* Dr. sc. D. Bilić, dipl.oec., pročelnik Gradskog ureda za prostorno uređenje, izgradnju Grada, graditeljstvo, komunalne poslove i promet, Grad Zagreb (e-mail: dinko.bilic@zagreb.hr). Rad je primljen u uredništvo 30.11.2018. godine, a prihvaćen je za objavu 12.12.2018. godine 


\section{Uvod}

Suvremeni turizam i komuniciranje postali su nezamislivi bez upotrebe Interneta i moderne tehnologije pri čemu poseban značaj ima upotreba društvenih mreža.

U tom se kontekstu u znanstvenoj i stručnoj literaturi sve više spominje i razrađuje pojam e-turizam (Buhalis i Jun, 2011) uz pojam e-komunikacije (Saravanakumar i Sugantha Lakshmi, 2012), koji odražavaju digitalizaciju svih procesnih i vrijednosnih lanaca u turizmu i ugostiteljstvu općenito kako bi se postigla najviša razina učinkovitosti turističke destinacije. Kad se uzme u obzir činjenica da je svrha promocije turističke destinacije informirati aktualne i potencijalne posjetitelje o turističkoj ponudi destinacije i prezentirati turističke aktivnosti na toj destinaciji putem raznih medija, s naglaskom na nove informacijske i komunikacijske tehnologije (ICT), može se reći da Zagreb u posljednjih desetak godina aktivno prati svjetske trendove. Recentno istraživanje „Zagreb Visitor Survey 2017/18“, provedeno za Turističku zajednicu Grada Zagreba pokazuje da je od 44 posto posjetitelja u Hrvatskoj (s izuzetkom domaćih gostiju) 31 posto njih posjetilo Zagreb (Donnell i Anderson, 2018). Navedeno istraživanje, provedeno od svibnja 2017. do travnja 2018. ispitivalo je, među ostalim, i navike zagrebačkih gostiju, način dolaska, smještaja i rezervacije i razloge posjeta, a više od 93 posto ispitanih je potvrdilo da je Zagreb posjetilo u prosincu upravo zbog manifestacije Advent $\mathrm{u}$ Zagrebu (Donnell i Anderson, 2018).

Uzimajući u obzir da glavni grad Hrvatske bilježi povećani priljev gostiju u prosincu, anketni upitnik za potrebe ovog rada, u kojemu su turisti na turističkoj destinaciji Zagreb ocjenjivali informiranost, mogućnosti komuniciranja, važnost i zastupljenost informativno-komunikacijskih medija, proveden je od rujna 2017. do veljače 2018. godine, pri čemu je u prosincu ispunjeno najviše anketa. Vrijeme adventa također je pokazalo da je čak 39 posto ispitanih turista koristilo mogućnost on-line komunikacije s agentima za rezervaciju smještaja (Donnell i Anderson, 2018) što je dalo dodatan poticaj za ispitivanje utjecaja ICT-a na poboljšanje učinkovitosti turističke destinacije. Pregledom literature uočeno je da je u stručnim proučavanjima navedenih pojava znatno veći fokus bio na tome kako turisti koriste Internet i društvene mreže pri planiranju i odabiru turističke destinacije (Sheller i Urry, 2004; Zekanović-Korona i Klarin, 2012). Međutim, pod utjecajem tehnološkog razdoblja potrošač, odnosno turist postao je zahtjevniji (Buhalis, 1998) i sve više se o sadržajima određenog turističkog prostora interesira na licu mjesta, odnosno u trenutku kad se nalazi na već odabranoj turističkoj destinaciji. Uzme li se u obzir da je stvaranje cjelokupnog turističkog doživljaja podijeljen na faze (Clawson i Knetsch, 1966; Gunn, 1972), odnosno da je on rezultat komunikacijskih procesa koji počinju još od planiranja putovanja i odabira destinacije, nastavljaju se na samoj turističkoj destinaciji i završavaju povratkom i prepričavanjem svo- 
jeg iskustva drugima, jasno je da istraživanja vezana za komunikacijske procese i turizam moraju obuhvatiti sve faze u oblikovanju turističkog doživljaja. Pri tome, e-komunikacija postaje sve zastupljenija u odnosu na neposrednu komunikaciju s ponuditeljima usluge i domicilnim stanovništvom. Razvojem informacijskih i komunikacijskih tehnologija (ICT) turizam je posljednjih nekoliko desetljeća doživio niz promjena, a tehnološka revolucija pružila je brojne alate za razvoj turizma (Baldigara, Štambuk i Mamula, 2013) pri čemu je izuzetno važno voditi računa o tome da svaka informacija dođe u pravo vrijeme.

Globalno tržište razvilo se u tolikoj mjeri da njegovi korisnici imaju sve veću fleksibilnost i slobodu u korištenju mrežnih komunikacija (Kučiš, 2016) što je utjecalo na inoviranje turističke ponude i promijenilo razinu učinkovitosti svih dionika na destinaciji. Društvene mreže doprinijele su bržem i kvalitetnijem poslovnom komuniciranju (Kučiš, Plenković, Plenković i Mustić, 2015). Stoga je svrha ovoga istraživanja, uslijed očigledne ekspanzije korištenja Interneta i društvenih mreža na globalnom tržištu, utvrditi sve veću potrebu za informacijskim i komunikacijskim tehnologijama tijekom svog boravka na određenoj turističkoj destinaciji, uzimajući u obzir da se turist sve aktivnije uključuje u kreiranje sadržaja, a ta neizostavna aktivnost u velikoj mjeri utječe na preispitivanje i podizanje razine učinkovitosti turističke destinacije.

\section{Pregled literature i dosadašnjih istraživanja}

Analizom prethodnih istraživanja i stručne literature o utjecaju informacijskih i komunikacijskih tehnologija na turistički sektor može se zaključiti da su mobilna tehnologija i upotreba društvenih mreža i aplikacija (Facebook, Instagram, YouTube, Tripadvisor, WhatsApp, Pinterest, Snapchat, Twitter i dr.) znatno utjecale na inoviranje turističke ponude, kao i na sam odabir destinacije i boravak na njoj (Buhalis i Law, 2008; Gretzel i Hyan Yoo, 2008; Xiang i Gretzel, 2010). Društvene mreže postale su globalni komunikacijski fenomen jer korisnici imaju mogućnost aktivnog sudjelovanja u kreiranju sadržaja, što im daje osjećaj pripadnosti (Ganim Barnes, Mattson i Marušić, 2008). »Za turiste vrlo značajnu ulogu ima dostupnost informacijama prilikom donošenja odluke o putovanju, pri čemu primjena ICT-a ne samo da smanjuje nesigurnost i mogući rizik, već dodatno povećava kvalitetu putovanja « (Mihajlović 2013, str. 70). Internet je imao velik utjecaj na turizam, o čemu svjedoči i porast broja istraživanja teme pretraživanja informacija, analize web-stranica i internetskog marketinga (Standing, Tang-Taye i Boyer, 2014).

Razvojem tehnologija na informacijskom polju formirao se jedan sasvim novi način komuniciranja, odnosno sustav mobilne komunikacije koja, prije svega, 
služi brzoj razmjeni informacija što je za turističku ponudu i njenu konkurentnost od presudnog značenja. Korisnici usluge dobili su platformu na kojoj samostalno mogu kreirati različite društvene sadržaje (Hoegg, Martignoni, Meckel i Stanoevska - Slabeva, 2006), iznositi mišljenja o određenim proizvodima i ponudi (npr. Tripadvisor), što je značajno utjecalo na promišljanje o uvođenju inovacija na destinaciji. Korištenje ICT-a, posebno Interneta, utjecalo je i na međunarodno poslovanje brojnih tvrtki, dok pojedini autori navode kako upotreba društvenih medija (mreža) u velikoj mjeri može olakšati poslovanje, odnosno smanjiti troškove (Stein i Zwass, 1995; Reuber i Fischer, 2011).

U predstavljenom informacijsko-komunikacijskom sustavu nikako ne treba zanemariti činjenicu da nisu svi subjekti jednako uspješni na digitalnom tržištu, premda informacijske i komunikacijske tehnologije prevladavaju u svim funkcijama strateškog i operativnog upravljanja. Posebno se to odnosi na područje turizma s obzirom na to da je informacija, smatra Buhalis (1998), ,žila kucavica“ turizma te će se brojne organizacije i odredišta, kako bi bili u konkurentnoj utrci, morati prilagoditi suvremenim tokovima u komunikacijskim kanalima. Buhalis (1998) nadalje navodi kako su istraživanja pokazala da će samo inovativni kreatori turističke politike biti konkurentni na tržištu te će destinacija koju predstavljaju imati dodanu vrijednost i zadovoljiti potrebe potrošača. E-poslovanje neophodni je preduvjet za uspješne organizacije u novom, globalno umreženom, internetskom okruženju, a to se posebno odnosi na turističku industriju (Buhalis i Jun, 2011).

Informacijske i komunikacijske tehnologije postale su neizostavne pri obavljanju brojnih poslova u turističkom sektoru poput izravnog kontakta s klijentima, zabave i usluge za klijente, komunikacije s kupcima i partnerima, navode autori Zekanović-Korona i Klarin (2012). Isti autori također ističu da se prva značajnija primjena informacijskih sustava, baza podataka i računalnih mreža zbila uvođenjem turističkih rezervacijskih sustava. Napretkom tehnologije razvijali su se i rezervacijski sustavi sve do mogućnosti on-line rezervacije, a sve veća upotreba takve vrste organizacije putovanja, koja svoju ekspanziju doživljava krajem 20. stoljeća, dovela je i do većeg broja znanstvenih članaka i studija na tu temu (Bonn, Furr i Susskind, 1999; Gretzel i Hyan Yoo, 2008). Planiranje putovanja zahtjevan je proces i uključuje vrijeme, određenu dinamiku i donošenje odluka na nekoliko razina (Jeng i Fesenmaier, 2002), a Internet i mogućnosti novih tehnologija korisniku turističkih usluga dodatno olakšavaju proces rezervacija.

Mogućnost i autonomija prilikom organizacije putovanja dovela je do pojave novog profila potrošača, koji upotrebom ICT tehnologija mijenja odnos prema korištenju slobodnog vremena, mijenja vrijednosti i životni stil, odnosno mijenja svijest o vlastitim potrebama (Gretzel, Fesenmaierand i O’Leary, 2006). Slijedom navedenog, učinci tehnologije postali su bitni i u trenutku kad se turist nalazi na odabranoj destinaciji. Istraživačko iskustvo pokazuje da je turistička destinacija prostor koji je prožet mrežama međuovisnih odnosa, vezanih za turističku djelat- 
nost, a komuniciranje je na tom prostoru značajan segment koji omogućava bolju povezanost svih onih elemenata koji zajedno, u različitim kombinacijama, privlače turiste (Lumsdon, 1997).

\section{Zagreb kao turistička destinacija u okvirima hrvatskog turizma}

Marketinške i promotivne aktivnosti Hrvatske turističke zajednice (HTZ) posljednjih su se nekoliko godina usmjerile na što bolje pozicioniranje i brendiranje Hrvatske na globalnom tržištu, pa je Hrvatska tako u 2017. godini označena jednom od najpopularnijih rastućih destinacija, s porastom dolazaka turista od 13 posto i noćenja od 12 posto, u odnosu na prethodnu godinu (Ministarstvo turizma RH, 2017). Prema statističkim podacima procjena je resornog ministarstva da će hrvatski turizam bilježiti daljnji rast u gotovo svim segmentima. Pri tome se posebno naglašava kako se investicije u hrvatski turizam nastavljaju te kako se turistička potražnja i razvoj ne događaju samo na hrvatskoj obali. Tako su u kontinentalnom dijelu, navodi ministarstvo, gotovo sve županije u 2017. zabilježile porast prometa, dok se među proizvodima dosta »ulaže i razvija cikloturizam te drugi posebni oblici ponude, uključujući ruralni, kongresni, zdravstveni, kulturni, adrenalinski i riječni turizam« (Ministarstvo turizma RH, 2017). Prema istraživanju TOMAS Ljeto 2017. godine (Institut za turizam, 2018) 44 posto ispitanih turista istaknulo je da im je za izvor informacija o Hrvatskoj kao turističkoj destinaciji poslužio Internet. Međutim, znatno zanimljivije je to da je među ispitanima koji su odgovorili da su koristili Internet kao izvor informacija, čak 67 posto onih koji su se o Hrvatskoj interesirali putem društvenih mreža (Facebook, TripAdvisor, Instagram, Twitter...), što je za 39 posto više u odnosu na rezultate istraživanja provedenog 2014. godine (Institut za turizam, 2018). Razvoj i napredak turističke industrije u Hrvatskoj pokazuju i preliminarni podaci o ostvarenju prihoda od stranih turista kao i o njihovom udjelu u BDP-u. Hrvatski je turizam u 2017. ostvario devizne prihode u visini od 9,5 milijardi eura te je udio navedenih deviznih prihoda povećan s 13,8 (2010. godine) na 19,4 posto u 2017. godini (Ekonomski institut Zagreb, 2018).

Zagreb, kako je naglašeno i ranije, ide ukorak s uspješnim trendovima u nacionalnim okvirima. Premda je hrvatski turizam još uvijek orijentiran na obalna mjesta i gradove pa su najpopularnije turističke destinacije, prema broju ostvarenih noćenja, u 2017. godini bile Dubrovnik, Poreč i Rovinj (Ekonomski institut Zagreb, 2018) glavni grad ne zaostaje za najatraktivnijim nacionalnim destinacijama. Prema podacima Državnog zavoda za statistiku, promatra li se ukupni turistički promet na destinaciji kontinentalne Hrvatske, Zagreb je predvodnik u broju noćenja kojih je u 2017. zabilježio čak 2,3 milijuna. Navedene brojke pozicioniraju Zagreb kao turističku destinaciju koja postaje sve privlačnija turistima te je zbog 
toga bilo potrebno uložiti istraživački napor i utvrditi na koji način tehnološke inovacije mogu doprinijeti daljnjem razvoju i unapređivanju turističke ponude.

\section{Metodologija istraživanja}

Iznimno važan utjecaj informacijske i komunikacijske tehnologije u turizmu (e-turizam) promijenio je način pristupanja turističkim uslugama i način na koji se te usluge troše, a sveprisutni i vrlo inovativni ICT-i potrošačima pružaju različite kanale kojima pristupaju uslugama (Ukpabi i Karjaluoto, 2017; Garcia i Calantone, 2002). S obzirom na tu okolnost postavlja se istraživačko pitanje: Može li razvoj e-komunikacije pozitivno utjecati na podizanje razine učinkovitosti turističke destinacije grada Zagreba.

Podatci koji su predstavljeni u ovom radu rezultat su anketiranja turista koji su boravili na turističkoj destinaciji Zagreb. Popunjena su 202 anketna upitnika od čega je 188 pravilno popunjenih. Anketni upitnici sastavljeni su na hrvatskom i engleskom jeziku. Istraživanje je obuhvatilo turiste u dobi od 18 ili više godina, a provedeno je u razdoblju od rujna 2017. do veljače 2018. godine. Anketni upitnik sastoji se od pet dijelova. Prvi i drugi dio čine pitanja vezana za ocjenu informiranosti i mogućnosti komuniciranja na turističkoj destinaciji Zagreb, dok se treći i četvrti dio anketnog upitnika sastoje od pitanja koja se odnose na ocjenu važnosti i zastupljenosti informativno-komunikacijskih medija i e-komunikacije na turističkoj destinaciji Zagreb. Peti dio odnosi se na pitanja vezana za sociodemografski profil ispitanika.

Stupanj naklonjenosti ocjenjivan je Likertovom skalom s pet ocjena: 1- tvrdnji uopće nisam naklonjen/a, 2 - tvrdnji nisam naklonjena, 3 - ne mogu se odlučiti, 4 tvrdnji sam naklonjen/a, 5 - tvrdnji sam vrlo naklonjen/a). Istraživanje je obuhvatilo turiste koji su boravili u svim gradskim četvrtima na turističkoj destinaciji Zagreb.

\subsection{Temeljna obilježja uzorka}

Prema podatcima u tablici 1 evidentno je da je veća zastupljenost ženskog (66 \%) u odnosu na muški spol (34 \%) što čini razliku od $32 \%$. Kod obrazovne strukture skoro je jednak broj sa završenom srednjom $(42,6 \%)$ i visokom školom $(43,6 \%)$ dok je turista sa završenim magisterijem bilo tek 1,6 \%. Prema bračnom statusu uzorak je podijeljen na idealne polovine. Odgovori o državi podrijetla pokazuju, očekivano, različitu strukturu, pri čemu je 26,1\% domaćih turista, dok je od stranih najviše onih iz Italije i Austrije (po $9 \%$ ). 
Tablica 1.

\section{OPĆI PODATCI O ISPITANICIMA}

\begin{tabular}{|c|c|c|c|c|}
\hline & Frekvencija & Postotak & $\begin{array}{r}\text { Validni } \\
\text { postotak }\end{array}$ & $\begin{array}{c}\text { Kumulativni } \\
\text { postotak }\end{array}$ \\
\hline \multicolumn{5}{|l|}{ SPOL } \\
\hline Ženski & 124 & 66,0 & 66,0 & 66,0 \\
\hline Muški & 64 & 34,0 & 34,0 & 100,0 \\
\hline Ukupno & 188 & 100,0 & 100,0 & \\
\hline \multicolumn{5}{|l|}{ OBRAZOVANJE } \\
\hline Srednja škola & 80 & 42,6 & 42,6 & 42,6 \\
\hline Viša škola & 23 & 12,2 & 12,2 & 54,8 \\
\hline Visoka škola & 82 & 43,6 & 43,6 & 98,4 \\
\hline Magisterij & 3 & 1,6 & 1,6 & 100,0 \\
\hline Ukupno & 188 & 100,0 & 100,0 & \\
\hline \multicolumn{5}{|l|}{ BRAČNI STATUS } \\
\hline Udana/Oženjen & 94 & 50,0 & 50,0 & 50,0 \\
\hline Neudana/ Neoženjen & 94 & 50,0 & 50,0 & 100,0 \\
\hline Ukupno & 188 & 100,0 & 100,0 & \\
\hline \multicolumn{5}{|c|}{ DRŽAVA PODRIJETLA } \\
\hline Austrija & 17 & 50,0 & 9,0 & 9,0 \\
\hline Bosna i Hercegovina & 10 & 50,0 & 5,3 & 14,3 \\
\hline Brazil & 7 & 100,0 & 3,7 & 18,0 \\
\hline Češka & 5 & 2,7 & 2,7 & 20,7 \\
\hline Francuska & 14 & 7,4 & 7,4 & 28,1 \\
\hline Hrvatska & 49 & 26,1 & 26,1 & 54,2 \\
\hline Italija & 17 & 9,0 & 9,0 & 63,2 \\
\hline Japan & 6 & 3,2 & 3,2 & 66,4 \\
\hline Južna Koreja & 7 & 3,7 & 3,7 & 70,1 \\
\hline Kina & 5 & 2,7 & 2,7 & 72,8 \\
\hline Mađarska & 6 & 3,2 & 3,2 & 76,0 \\
\hline Njemačka & 11 & 5,9 & 5,9 & 81,9 \\
\hline Slovenija & 12 & 6,4 & 6,4 & 88,3 \\
\hline Velika Britanija & 6 & 3,2 & 3,2 & 91,5 \\
\hline Ostalo $^{1}$ & 16 & 8,5 & 8,5 & 100,0 \\
\hline Ukupno & 188 & 100,0 & 100,0 & \\
\hline
\end{tabular}

Izvor: Izradio autor prema provedenom istraživanju.

1 Makedonija, Nizozemska, Portugal, SAD, Slovačka, Srbija, Švedska, Švicarska. 
U anketi su sudjelovali ispitanici u dobi od 18 do 60 godina, a deskriptivnom statističkom analizom došlo je do izračuna da je prosječna starost ispitanika 33 godine što je prikazano u tablici br. 2.

Tablica 2.

DOB ISPITANIKA

\begin{tabular}{|c|c|c|c|c|c|c|}
\hline 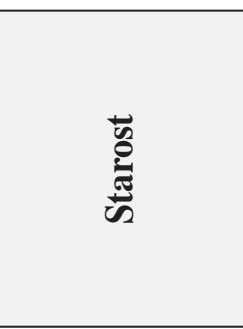 & 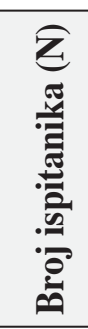 & 春 & 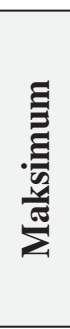 & שَّ & 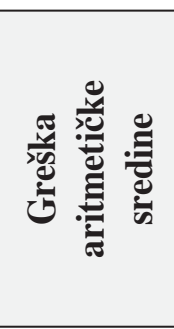 & 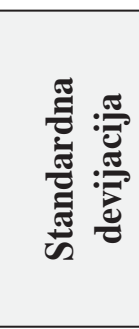 \\
\hline & 188 & 18 & 60 & 33,54 & 0,754 & 10,343 \\
\hline $\begin{array}{l}\text { Validan broj } \\
\text { ispitanika (N) }\end{array}$ & 188 & & & & & \\
\hline
\end{tabular}

Izvor: Izradio autor prema provedenom istraživanju.

Tablica br. 3 prikazuje podatke o obilježjima putovanja, odnosno podatke koji su vezani za društvo s kojim ispitanici najčešće putuju i razlog putovanja. Rezultati pokazuju da prevladava putovanje s obitelji (26,6 \%), supružnikom $(15,4$ $\%)$ te prijateljima $(23,4 \%)$. Najmanje ispitanika putuje s poslovnim partnerima $2,1 \%$ ispitivačkog uzorka. Kao razlog putovanja većina ispitanika, više od $70 \%$ njih, navodi odmor. Drugi razlozi putovanja su raspodijeljeni u manjim omjerima kako je i vidljivo u tablici 3. 
Tablica 3.

\section{OBILJEŽJA PUTOVANJA}

\begin{tabular}{|c|c|c|c|c|}
\hline & Frekvencija & Postotak & $\begin{array}{r}\text { Validni } \\
\text { postotak }\end{array}$ & Kumulativni postotak \\
\hline \multicolumn{5}{|c|}{ DRUŠTVO NA PUTOVANJU } \\
\hline $\mathrm{Sam} / \mathbf{a}$ & 25 & 13,3 & 13,3 & 13,3 \\
\hline Partner/ica & 6 & 3,2 & 3,2 & 16,5 \\
\hline Suprug/a & 29 & 15,4 & 15,4 & 31,9 \\
\hline Kolega/ica & 11 & 5,9 & 5,9 & 37,8 \\
\hline Obitelj & 50 & 26,6 & 26,6 & 64,4 \\
\hline Poslovni partner & 4 & 2,1 & 2,1 & 66,5 \\
\hline Prijatelj/ica & 44 & 23,4 & 23,4 & 89,9 \\
\hline Agencija-grupa & 19 & 10,1 & 10,1 & 100,0 \\
\hline Ukupno & 188 & 100,0 & 100,0 & \\
\hline \multicolumn{5}{|c|}{ RAZLOG PUTOVANJA } \\
\hline Odmor & 132 & 70,2 & 70,2 & 70,2 \\
\hline Poslovni & 35 & 18,6 & 18,6 & 88,8 \\
\hline Kulturni & 3 & 1,6 & 1,6 & 90,4 \\
\hline Sportski & 4 & 2,1 & 2,1 & 92,6 \\
\hline Vjerski & 1 & 0,5 & 0,5 & 93,1 \\
\hline Avanturistički & 2 & 1,1 & 1,1 & 94,1 \\
\hline Prijateljski & 6 & 3,2 & 3,2 & 97,3 \\
\hline Uživanje & 5 & 2,7 & 2,7 & 100,0 \\
\hline Ukupno & 188 & 100,0 & 100,0 & \\
\hline
\end{tabular}

Izvor: Izradio autor prema provedenom istraživanju. 


\section{Rezultati deskriptivne statističke analize}

Za potrebe istraživanja u ovom radu provedena je deskriptivna statistička analiza čiji će rezultati biti prikazani u ovom poglavlju i to za svaki dio anketnog upitnika.

Prvi dio anketnog upitnika odnosi se na ocjenu informiranosti turista na turističkoj destinaciji Zagreb. Rezultati uključuju petnaest varijabli i prikazani su u tablici br. 4. Pregledom tablice vidljivo je da ispitanici u prosjeku izražavaju zadovoljstvo informiranošću na turističkoj destinaciji Zagreb pri čemu se kao najveća prednost ističe informiranje preko prijatelja i poznanika koji su posjetili Zagreb $(\mathrm{M}=4,46)$, laka dostupnost svih turističkih atrakcija $(\mathrm{M}=4,4)$, pravodobna obavijest o događajima na destinaciji $(M=4,31)$, internetske stranice turističke destinacije $(M=4,22)$ te društvene mreže $(M=4,13)$.

\section{Tablica 4 .}

\section{OCJENA INFORMIRANOSTI TURISTA NA TURISTIČKOJ DESTINACIJI ZAGREB}

\begin{tabular}{|c|c|c|c|c|c|c|}
\hline 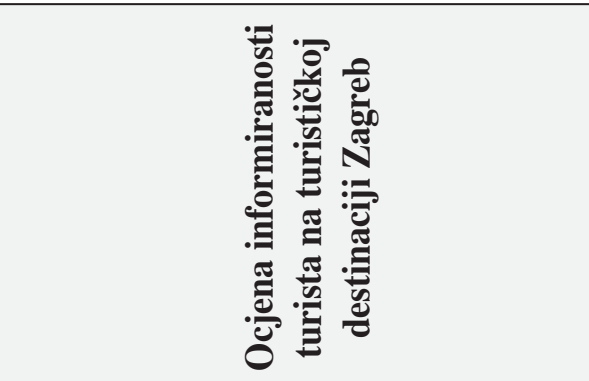 & 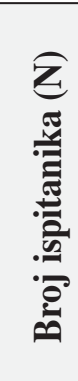 & 咅 & 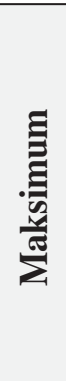 & 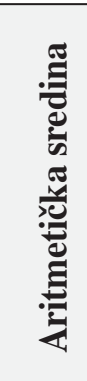 & 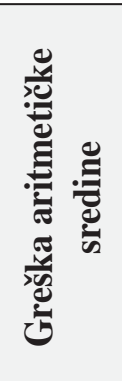 & 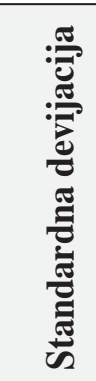 \\
\hline $\begin{array}{l}\text { Prijatelji i poznanici kao izvor } \\
\text { informacija }\end{array}$ & 188 & 3 & 5 & 4,46 & 0,047 & 0,640 \\
\hline Lagan pronalazak turističkih točki & 188 & 2 & 5 & 4,40 & 0,049 & 0,667 \\
\hline $\begin{array}{l}\text { Zaposleni u restoranima, kafićima } \\
\text { i recepcijama hotela kao izvor } \\
\text { informacija }\end{array}$ & 188 & 2 & 5 & 4,40 & 0,048 & 0,658 \\
\hline $\begin{array}{l}\text { Pravodobna obaviještenost } 0 \\
\text { događajima }\end{array}$ & 188 & 2 & 5 & 4,31 & 0,051 & 0,694 \\
\hline $\begin{array}{l}\text { Web-stranice destinacije kao izvor } \\
\text { informacija }\end{array}$ & 188 & 2 & 5 & 4,22 & 0,051 & 0,702 \\
\hline $\begin{array}{l}\text { Spotovi na društvenim mrežama kao } \\
\text { izvor informacija }\end{array}$ & 188 & 2 & 5 & 4,15 & 0,054 & 0,745 \\
\hline
\end{tabular}




\begin{tabular}{|c|c|c|c|c|c|c|}
\hline 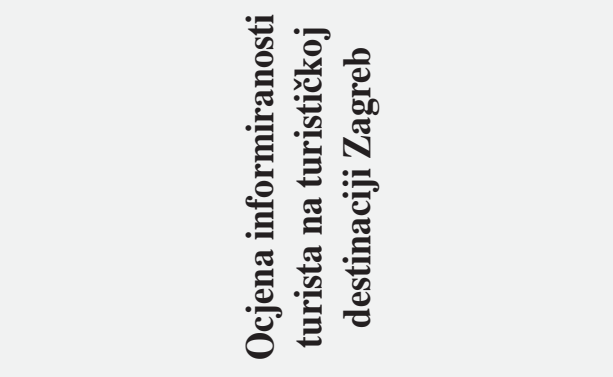 & 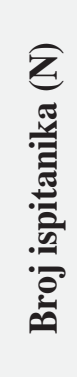 & 志 & 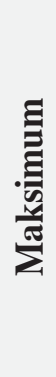 & 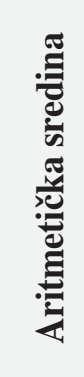 & 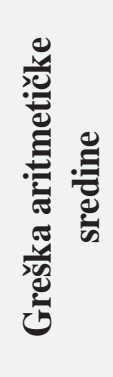 & 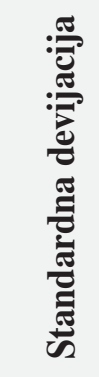 \\
\hline $\begin{array}{l}\text { Stanovnici grada Zagreba, slučajni } \\
\text { prolaznici, kao izvor informacija }\end{array}$ & 188 & 2 & 5 & 4,10 & 0,058 & 0,798 \\
\hline $\begin{array}{l}\text { Pravodobno usmjeravanje putem } \\
\text { prometnih znakova }\end{array}$ & 188 & 2 & 4 & 3,94 & 0,222 & 0,747 \\
\hline $\begin{array}{l}\text { Uređen sustav informacija za } \\
\text { olakšano kretanje }\end{array}$ & 188 & 2 & 5 & 3,85 & 0,055 & 0,748 \\
\hline $\begin{array}{l}\text { Prospekti i brošure turističkih } \\
\text { agencija kao izvor informacija }\end{array}$ & 188 & 2 & 5 & 3,84 & 0,054 & 0,745 \\
\hline $\begin{array}{l}\text { Pregledna i uredna označenost naziva } \\
\text { ulica, mostova, parkova, zdravstvenih, } \\
\text { kulturnih, sportskih i upravnih } \\
\text { objekata }\end{array}$ & 188 & 2 & 5 & 3,82 & 0,064 & 0,875 \\
\hline $\begin{array}{l}\text { Dežurno osoblje u turističkim } \\
\text { informativnim centrima kao izvor } \\
\text { informacija }\end{array}$ & 188 & 2 & 5 & 3,82 & 0,057 & 0,785 \\
\hline $\begin{array}{l}\text { Javne redarstvene i policijske službe } \\
\text { kao izvor informacija }\end{array}$ & 188 & 1 & 5 & 3,79 & 0,071 & 0,967 \\
\hline $\begin{array}{l}\text { Informativne radijske emisije na } \\
\text { svjetskim jezicima kao pomoć za } \\
\text { pronalazak odredišta }\end{array}$ & 188 & 1 & 5 & 3,60 & 0,064 & 0,875 \\
\hline $\begin{array}{l}\text { Dovoljan broj natpisnih ploča s } \\
\text { geografskim kartama na pravim } \\
\text { točkama (važna križanja ulica) }\end{array}$ & 188 & 1 & 5 & 3,58 & 0,077 & 1,049 \\
\hline Validni broj ispitanika & 188 & & & & & \\
\hline
\end{tabular}

Izvor: Izradio autor prema provedenom istraživanju .

Drugi dio anketnog upitnika odnosi se na ocjenu mogućnosti komuniciranja na turističkoj destinaciji Zagreb. Tablica prikazuje trinaest varijabli. Rezultati analize pokazuju da u prosjeku turisti pozitivno ocjenjuju mogućnosti komuniciranja na destinaciji i pritom se kao najzastupljenije ističe mogućnost komuniciranja sa stanovnicima grada $(M=4,59)$, sa sudionicima turističke ponude $(M=4,49)$ te zaposlenima i predstavnicima u objektima prehrane $(M=4,35)$. Rezultati ujedno prikazuju manjak komunikacije s turističkim animatorima $(M=2,86)$ što nam 
govori ili o trendu napuštanja takvog vida komunikacije ili o potrebi za unapređenjem i inovacijama navedenog komunikacijskog modela.

\section{Tablica 5 .}

\section{OCJENA MOGUĆNOSTI KOMUNICIRANJA NA TURISTIČKOJ DESTINACIJI ZAGREB}

\begin{tabular}{|c|c|c|c|c|c|c|}
\hline 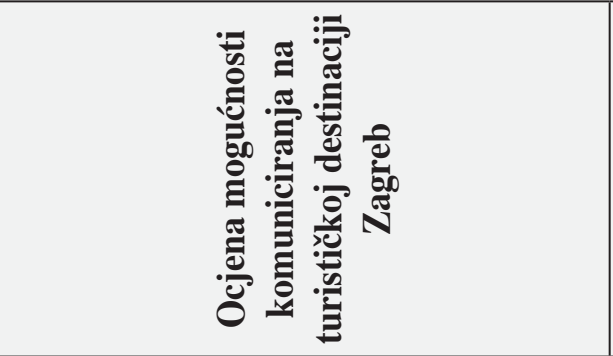 & 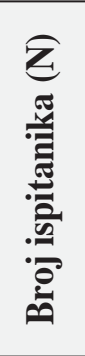 & 志 & 䒠 & 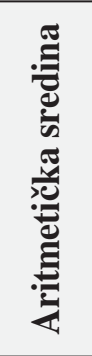 & 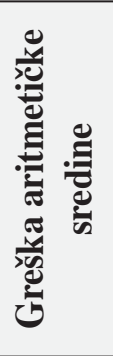 & 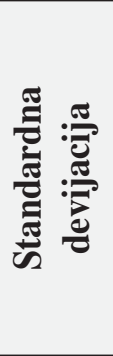 \\
\hline $\begin{array}{l}\text { Komuniciranje sa stanovnicima } \\
\text { grada, koji su otvoreni za } \\
\text { komunikaciju }\end{array}$ & 188 & 3 & 5 & 4,59 & 0,043 & 0,583 \\
\hline $\begin{array}{l}\text { Komuniciranje sa sudionicima } \\
\text { turističke ponude }\end{array}$ & 188 & 3 & 5 & 4,49 & 0,045 & 0,616 \\
\hline $\begin{array}{l}\text { Komuniciranje sa zaposlenima u } \\
\text { objektima prehrane }\end{array}$ & 188 & 2 & 5 & 4,35 & 0,059 & 0,803 \\
\hline Komuniciranje sa svojim suputnicima & 188 & 1 & 5 & 4,31 & 0,058 & 0,796 \\
\hline $\begin{array}{l}\text { Komuniciranje s osobljem na } \\
\text { recepciji smještajnih objekata }\end{array}$ & 188 & 1 & 5 & 4,26 & 0,058 & 0,796 \\
\hline Komuniciranje s drugim turistima & 188 & 1 & 5 & 4,22 & 0,058 & 0,796 \\
\hline $\begin{array}{l}\text { Komuniciranje s osobljem u } \\
\text { turističko- informativnim centrima }\end{array}$ & 188 & 1 & 5 & 4,15 & 0,058 & 0,795 \\
\hline $\begin{array}{l}\text { Komuniciranje sa slučajnim } \\
\text { prolaznicima }\end{array}$ & 188 & 3 & 5 & 3,93 & 0,058 & 0,795 \\
\hline Komuniciranje s turističkim vodičima & 188 & 1 & 5 & 3,80 & 0,069 & 0,949 \\
\hline $\begin{array}{l}\text { Komuniciranje s organizatorima } \\
\text { kulturnih događaja }\end{array}$ & 188 & 1 & 5 & 3,36 & 0,287 & 0,939 \\
\hline Komuniciranje s kustosima muzeja & 188 & 1 & 5 & 3,06 & 0,085 & 1,166 \\
\hline $\begin{array}{l}\text { Komuniciranje s organizatorima } \\
\text { sportskih događaja }\end{array}$ & 188 & 1 & 5 & 3,03 & 0,095 & 1,308 \\
\hline $\begin{array}{l}\text { Komuniciranje s animatorima na } \\
\text { priredbama za zabavu }\end{array}$ & 188 & 1 & 5 & 2,86 & 0,082 & 1,126 \\
\hline Validni broj ispitanika & 188 & & & & & \\
\hline
\end{tabular}

Izvor: Izradio autor prema provedenom istraživanju. 
Tablica 6 prikazuje rezultate deskriptivne statističke analize koji se odnose na ocjenu važnosti informativno-komunikacijskog medija za turiste. Predmetni dio istraživanja sadrži devet varijabli pri čemu su ispitanici ocijenili važnim informativno-komunikacijski medij i pritom se kao najvažnije izdvaja dostupnost Interneta u smještajnim kapacitetima $(\mathrm{M}=4,67)$, u restoranima i drugim ugostiteljskim objektima za prehranu $(\mathrm{M}=4,67)$ te kafićima i drugim ugostiteljskim objektima $(\mathrm{M}=$ 4,61). U manjoj je mjeri zastupljena važnost komuniciranja s nositeljima ponude ( $\mathrm{M}$ $=4,34)$ te $\mathrm{s}$ domicilnim stanovništvom $(\mathrm{M}=4,32)$ na turističkoj destinaciji.

\section{Tablica 6.}

\section{OCJENA VAŽNOSTI INFORMATIVNO-KOMUNIKACIJSKIH MEDIJA NA TURISTIČKOJ DESTINACIJI ZAGREB}

\begin{tabular}{|c|c|c|c|c|c|c|}
\hline 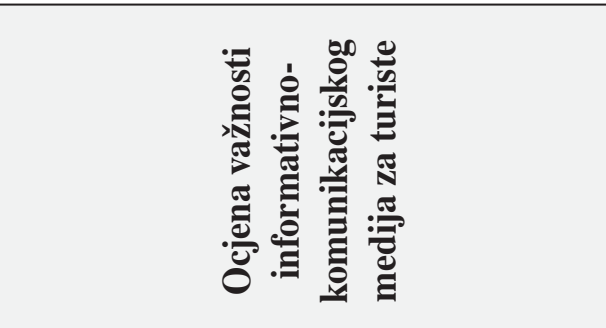 & 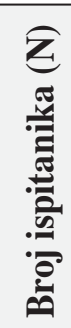 & 志 & 䒠 & 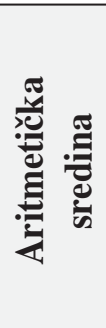 & 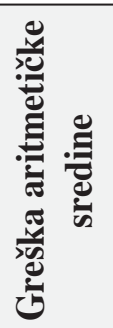 & 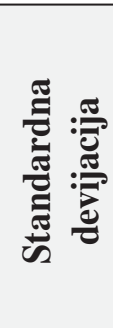 \\
\hline $\begin{array}{l}\text { Internetska povezanost u smještajnim } \\
\text { objektima }\end{array}$ & 188 & 2 & 5 & 4,67 & 0,038 & 0,525 \\
\hline $\begin{array}{l}\text { Internetska povezanost u restoranima } \\
\text { i drugim objektima prehrane }\end{array}$ & 188 & 3 & 5 & 4,67 & 0,038 & 0,515 \\
\hline $\begin{array}{l}\text { Internetska povezanost u lokalima i } \\
\text { kafićima }\end{array}$ & 188 & 3 & 5 & 4,65 & 0,038 & 0,520 \\
\hline Moć i kvaliteta signala mobilne telefonije & 188 & 2 & 5 & 4,61 & 0,041 & 0,561 \\
\hline $\begin{array}{l}\text { E-komunikacija s nositeljima ponude } \\
\text { za rezervacije smještaja }\end{array}$ & 188 & 3 & 5 & 4,57 & 0,040 & 0,548 \\
\hline $\begin{array}{l}\text { E-komunikacija s lokalnim } \\
\text { agencijama za sastavljanje programa } \\
\text { putovanja }\end{array}$ & 188 & 3 & 5 & 4,54 & 0,040 & 0,550 \\
\hline $\begin{array}{l}\text { E-komunikacija s nositeljima ponude } \\
\text { za dogovaranje i naručivanje usluga }\end{array}$ & 188 & 3 & 5 & 4,51 & 0,044 & 0,607 \\
\hline $\begin{array}{l}\text { Neposredna komunikacija } s \\
\text { nositeljima ponude }\end{array}$ & 188 & 1 & 5 & 4,34 & 0,052 & 0,709 \\
\hline $\begin{array}{l}\text { Komuniciranje s domicilnim } \\
\text { stanovništvom }\end{array}$ & 188 & 2 & 5 & 4,32 & 0,049 & 0,675 \\
\hline Validni broj ispitanika & 188 & & & & & \\
\hline
\end{tabular}

Izvor: Izradio autor prema provedenom istraživanju. 
Četvrti dio anketnog upitnika odnosi se na ocjenu zastupljenosti informativno-komunikacijskih medija na turističkoj destinaciji Zagreb. Rezultati navedenog dijela uključuju sedam varijabli. Zastupljenost informativno-komunikacijskih medija na turističkoj destinaciji Zagreb u prosjeku je pozitivno ocijenjena. Rezultati su prikazani u tablici br. 7.

\section{Tablica 7.}

\section{OCJENA ZASTUPLJENOSTI INFORMATIVNO-KOMUNIKACIJSKIH MEDIJA NA TURISTIČKOJ DESTINACIJI ZAGREB}

\begin{tabular}{|c|c|c|c|c|c|c|}
\hline 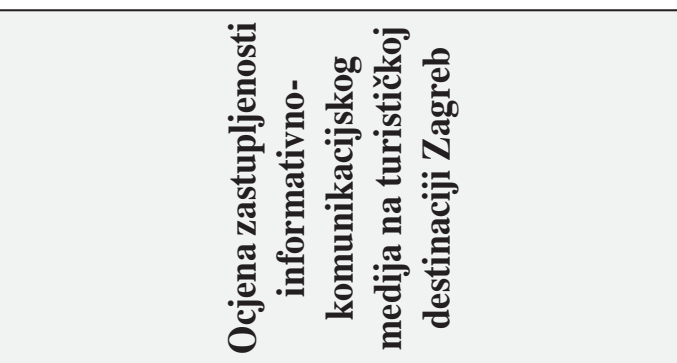 & 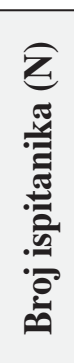 & 志 & 䒠 & 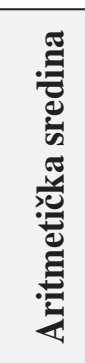 & 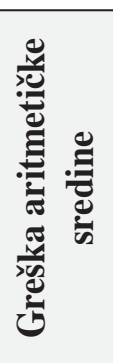 & 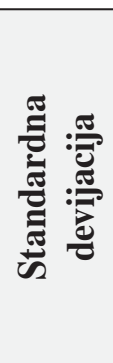 \\
\hline Domicilno stanovništvo & 188 & 3 & 5 & 4,53 & 0,043 & 0,589 \\
\hline Osoblje objekata prehrane i drugih lokala & 188 & 3 & 5 & 4,47 & 0,044 & 0,607 \\
\hline $\begin{array}{l}\text { Kvalitetan signal mobilne telefonije na } \\
\text { svim točkama turističke destinacije } \\
\text { Zagreb }\end{array}$ & 188 & 3 & 5 & 4,47 & 0,044 & 0,607 \\
\hline Osoblje smještajnih objekata & 188 & 2 & 5 & 4,39 & 0,048 & 0,657 \\
\hline $\begin{array}{l}\text { Internetska povezanost na svim točkama } \\
\text { turističke destinacije Zagreb }\end{array}$ & 188 & 3 & 5 & 4,16 & 0,053 & 0,731 \\
\hline $\begin{array}{l}\text { Prospekti i brošure na svim točkama } \\
\text { turističko-informativnog centra }\end{array}$ & 188 & 3 & 5 & 4,16 & 0,052 & 0,709 \\
\hline $\begin{array}{l}\text { Prospekti i brošure na stranim jezicima } \\
\text { na svim točkama turističko-informativnog } \\
\text { centra }\end{array}$ & 188 & 3 & 5 & 4,15 & 0,052 & 0,711 \\
\hline Validni broj ispitanika & 188 & & & & & \\
\hline
\end{tabular}

Izvor: Izradio autor prema provedenom istraživanju. 
D. BILIĆ: Utjecaj e-komunikacije na podizanje razine učinkovitosti turističke destinacije grada Zagreba EKONOMSKI PREGLED, 70 (6) 849-868 (2019)

\subsection{Analiza ocjene turista o komunikacijskim procesima na turističkoj de- stinaciji Zagreb}

Prethodno predstavljeni rezultati deskriptivne statističke analize pokazali su da turisti na turističkoj destinaciji Zagreb pozitivno ocjenjuju informiranost i mogućnosti komuniciranja kao i važnost informativno-komunikacijskih medija i zastupljenost e-komunikacije na turističkoj destinaciji Zagreb. Kada je riječ o samoj informiranosti, rezultati pokazuju kako je još uvijek u velikoj mjeri zastupljena neposredna komunikacija, a informiranost se realizira najčešće preko prijatelja i poznanika koji su već boravili u Zagrebu ili preko zaposlenih u smještajnim i ugostiteljskim objektima. Ipak, vidljivo je da se informiranost turista postiže i putem Interneta i društvenih mreža i to u većem stupnju od dobivanja informacija od zaposlenih u turističko-informativnim centrima čime se može utvrditi da postoji intenzivan rast i razvoj digitalizacije u komunikacijskom procesu te je pitanje koliko će se brzo navedena pojava nastaviti razvijati i kakav će utjecaj imati na proces traženja i zaprimanja potrebnih informacija na turističkoj destinaciji. Nadalje, pozitivna ocijenjenost mogućnosti komuniciranja na turističkoj destinaciji Zagreb ipak ne znači da u tom dijelu komunikacijskog sustava nisu potrebne promjene ili inovacije. Naime, turisti smatraju da je komunikacija s domicilnim stanovništvom u dovoljnoj mjeri zastupljena i dostupna s obzirom na činjenicu da domicilno stanovništvo bez problema komunicira s gostima i otvoreno je za komunikaciju. Isto tako smatraju da su nositelji ponude, zaposleni u hotelima, i ostalim smještajnim objektima, objektima prehrane i drugim ugostiteljskim lokalima spremni za komunikaciju s gostima te, stoga, često s njima komuniciraju s ciljem informiranja o turističkoj destinaciji. S druge strane rezultati su pokazali i prisutnost mogućnosti komuniciranja s kustosima muzeja ili animatorima, ali tu se opaža manjak iskoristivosti takve vrste komunikacije zbog čega se može postaviti pitanje je li navedena situacija rezultat mijenjanja trendova i potrebe za inovacijama u tim segmentima, točnije, hoće li, na primjer, kustose kao izvor informiranja na izložbama u muzejima zamijeniti danas sve popularniji QR kodovi te hoće li u animacijskim programima u budućnosti biti potrebno služiti se novim tehnološkim i digitalnim rješenjima kako bi takva vrsta komunikacije opstala i bila relevantan izvor informacija za turiste na turističkoj destinaciji.

Ispitani turisti ocijenili su važnima informativno-komunikacijske medije na turističkoj destinaciji. Pritom, ulogu najvažnijeg informativno-komunikacijskog medija ima internetska povezanost, a naročito je bitno njezino postojanje u smještajnim objektima i lokalima s ugostiteljskom uslugom. Rezultati istraživanja pokazali su da je neposredna e-komunikacija s nositeljima ponude način na koji turisti najčešće obavljaju rezervacije svog smještaja i planiraju putovanje, ali i način kojim dogovaraju i rezerviraju usluge na licu mjesta, odnosno na samoj turističkoj destinaciji. 
Kada je riječ o zastupljenosti informativno-komunikacijskih medija, i dalje je za turiste najdostupnija komunikacija s građanima i zaposlenima u uslužnim djelatnostima. Prema ispitanom uzorku, na turističkoj destinaciji Zagreb postoji dovoljan broj prospekata i brošura na svim točkama turističko-informativnog centra, ali turistima koji su bili dio istraživanja važnija je zastupljenost internetske povezanosti i kvalitetnog signala mobilne telefonije za dobivanje potrebnih informacija.

Temeljem prikazanih rezultata može se doći do zaključka da u vrijeme tehnološkog razvoja i ekspanzije e-komunikacije još uvijek značajnu ulogu ima neposredna komunikacija turista s domicilnim stanovništvom i nositeljima turističke ponude, ali da je za razvoj konkurentnosti i učinkovitu prilagodbu destinacije aktualnim trendovima i potrebama ključna implementacija novih tehnologija digitalne komunikacije i mobilne industrije. Provedeno istraživanje predstavlja inicijativu za nove načine razmišljanja i djelovanja kad je riječ o osiguranju uspješnosti neke turističke destinacije. Naime, današnja situacija na tržištu uvjetuje potrebu za pravovremenim prepoznavanjem činjenice da se dosadašnja praksa u kojoj su se najviše cijenili znanje i vještine mijenja te da za stvaranje učinkovite turističke destinacije s konkurentnom ponudom sve važnije postaje sposobnost implementacije inovacijskih, u konkretnom slučaju, informacijsko-tehnoloških procesa. Svi sudionici u kreiranju turističke ponude moraju postati svjesni da novi turist (Buhalis i O'Connor, 2005) ili novi gost (Magaš, 2018) postaje sve zahtjevniji, aktivniji, željan znanja te mu je vrijeme bitna odrednica u planiranju putovanja, nema vremena za čekanje i traži lako dostupnu i brzu razmjenu informacija (Buhalis i O'Connor, 2005). Signifikantno je upravo to da je istraživanje, provedeno na destinaciji grada Zagreba pokazalo kako turisti, unatoč činjenici da im je Internet na destinaciji dostupan, ne zanemaruju komunikaciju s domicilnim stanovništvom, a ponudu i informacije potražit će i u turističkim centrima te u neposrednom kontaktu sa zaposlenima u turizmu i ugostiteljskim djelatnostima. Ipak, dostupnost Interneta i mogućnost brzog pronalaženja informacija mogu se smatrati ključnima za turiste i njihovu percepciju o učinkovitosti pojedine destinacije.

\section{Zaključak}

Tehnološke inovacije i razvoj informacijskih i komunikacijskih tehnologija unijele su značajne promjene u sve sfere društvenog života i ljudskog djelovanja. Pregledom dosad objavljenih znanstvenih i stručnih članaka na ovu temu može se zaključiti kako su tehnološki napredak i neprestani proces inovacija u tom segmentu najsnažniji utjecaj izvršili upravo u domeni komunikacije i komuniciranja, a ubrzana razmjena informacija dovela je do sasvim nove dimenzije komunikacij- 
skih aktivnosti. Najsnažniji utjecaj na pojavu i razvoj spomenute dimenzije ima upravo Internet te se na globalnom tržištu implementirao pojam e-komunikacije koja je svojom pojavom unijela niz radikalnih promjena u poslovnim i privatnim odnosima. Jedna od društvenih sfera u kojoj je e-komunikacija postala neizostavan dio upravo je turizam. Istraživanja vezana za komunikacijske procese i načine razmjene informacija, s posebnim naglaskom na e-komunikaciju u turizmu, predstavljaju bitnu komponentu za razumijevanje razvoja novih trendova čijom se implementacijom utječe na održavanje i podizanje učinkovitosti turističke destinacije. Slijedom navedenog, provedeno je istraživanje o potrebama i navikama turista koji borave na destinaciji grada Zagreba s naglaskom na komunikacijske aspekte boravka, a s ciljem uvida u to na koji način različiti vidovi komunikacije (neposredna i e-komunikacija) utječu na podizanje razine učinkovitosti destinacije.

Važnost ovakve vrste istraživanja pokazuju upravo rezultati empirijskog dijela rada. Naime, anketiranjem turista na području turističke destinacije Zagreb i analizom njihovih odgovora vezanih za informiranost i mogućnosti komuniciranja te za zastupljenost informativno-komunikacijskih medija i e-komunikacije, prikazana je trenutna situacija u funkcioniranju razmjene informacija na destinaciji Zagreb, utvrđene su nove pojave koje sve više počinju utjecati na tu trenutnu situaciju, a detektirani su i određeni elementi koji zahtijevaju biti podvrgnuti inovacijskom procesu kako bi i dalje ostali funkcionalni u sve dinamičnijem informacijsko-komunikacijskom sustavu u turizmu. Bitno je istaknuti da su turisti na turističkoj destinaciji Zagreb pozitivno ocijenili informiranost i mogućnosti komuniciranja, ali njihovi odgovori u kojima ističu važnost dostupnosti internetske povezanosti ukazuju na to da će se morati nastaviti s ulaganjima u komunikacijsku infrastrukturu koja je uvjetovana postojanjem internetske mreže i signala, a takva vrsta ulaganja morat će biti, prije svega, inovativna kako bi zadovoljila današnje kriterije sve zahtjevnijih turista i kako bi se, u konačnici, osigurala učinkovitost i uspješnost same turističke destinacije. E-komunikacija, digitalizacija i pronalazak adekvatnih tehnoloških medija za brzu i jednostavnu razmjenu informacija sve više postaju prioriteti za zadovoljavanje potreba i želja samih turista što, naposljetku, rezultira pozitivnom povratnom informacijom i utječe na učinkovitost turističke destinacije. ICT sektor ima sve veći utjecaj u upravljanju turističkom destinacijom. Istraživanja koja su protekle dvije godine provedena u Hrvatskoj pokazuju da će i u budućnosti potrebe i zahtjevi turista sve više ovisiti o upotrebi društvenih mreža u svim segmentima organizacije putovanja - prije dolaska na destinaciju, tijekom boravka i nakon povratka s putovanja. Isto tako, uzimajući u obzir stavove turista, nositelji ponude morat će investirati u osmišljavanje i izradu novih digitalnih sustava kao novih ICT rješenja za što učinkovitije upravljanje ponudom turističke destinacije.

Ograničenja navedenog istraživanja pronalaze se u činjenici da je ono provedeno samo na jednoj turističkoj destinaciji u Hrvatskoj, ali s obzirom na trenutne trendove, pretpostavlja se da se rezultati istraživanja na drugim destinacijama ne 
bi previše razlikovali od ovdje predstavljenih, odnosno da bi ukazali na slične potrebe i smjerove za daljnji razvoj.

Iz rezultata provedenog istraživanja proizlazi potreba nastavka, odnosno kontinuiranog proučavanja općenito komunikacijskih procesa u turizmu. Navedeno je iznimno bitno s obzirom na dinamičnost, podložnost promjenama i nestalnost oba sustava - i komunikacijskog i turističkog. Ovaj znanstveni rad doprinosi jačanju istraživanja u fazi kada se turist već nalazi na turističkoj destinaciji i predstavlja podlogu za daljnja teorijska promišljanja i empirijska istraživanja.

\section{Literatura}

Baldigara, T., Štambuk, A. i Mamula, M. (2013). Contribution to e-tourism demand modelling, Informatologia, 46(4): 343-352.

Bonn, M., Furr, H. i Susskind, A. (1999). Predicting a behavioural profile for pleasure travelers on the basis of Internet use segmentation, Journal of Travel Research, 37(4): 330-340.

Buhalis, D. (1998). Strategic use of information technologies in the tourism industry, Tourism Management, 19(5): 409-421.

Buhalis, D. i O'Connor, P. (2005). Information communication technologyRevolutionising tourism. Tourism Recreation Research, 30(3): 7-16.

Buhalis, D. i Law, R. (2008). Progress in information technology and tourism management: 20 years on and 10 years after the Internet - The state of eTourism research, Tourism Management, 29(4): 609-623.

Buhalis, D. i Jun, Soo H. (2011). E-tourism. Chris Cooper (Ur.), Contemporary tourism reviews (str. 1-38). Oxford: Goodfellow Publishers Limited.

Clawson, M. i Knetsch, J.L. (1966). Economics of Outdoor Recreation. Baltimore: the Johns Hopkins Press for Resources for the Future, inc.

Donnell, N. i Anderson, T. (2018). Zagreb Visitor Survey 2017/18, Infographic Report. Dostupno na: http://www.infozagreb.hr/documents/b2b/ STRZagrebVisitorSurvey.pdf.

Ekonomski institut Zagreb. (2018). Sektor analize - Turizam. Zagreb: Ekonomski institut Zagreb.

Ganim Barnes, N., Mattson E. i Marušić, M. (2008). The INC. 500 and social media: Marketing research. Market-Tržište 20(1): 37-47.

Garcia, R. i Calantone, R. (2002). A critical look on innovation typology and innovativeness terminology. Product Innovation Menagement, 19(2): 110-132. 
D. BILIĆ: Utjecaj e-komunikacije na podizanje razine učinkovitosti turističke destinacije grada Zagreba EKONOMSKI PREGLED, 70 (6) 849-868 (2019)

Gretzel, U.,Fesenmaier,D.R.i O'Leary, J. (2006). The Transformation of Consumer Behaviour. D. Buhalis \& C. Costa (Ur.), Tourism Business Frontiers (str. 9-18). Burlington, MA: Elsevier.

Gretzel, U. i Hyan Yoo, K. (2008). Use and Impact of Online Travel Reviews. Peter O'Connor, Wolfram Höpken, Ulrike Gretzel (Ur.), Information and Communication Technologies in Tourism 2008. Wien: Springer.

Gunn, C. A. (1972). Vacationscape: Designing Tourist Regions. Austin: Bureau of Business Research, University of Texas at Austin.

Hoegg, R., Martignoni, R., Meckel, M. i Stanoevska - Slabeva, K. (2006). Overview of business models for Web 2.0 communities. Klaus Meißner i Martin Engelien (Ur.), Virtuelle Organisation und Neue Medien 2006 - Workshop GeNeMe 2006 (str. 33 - 35). Dresden: Technische Universität.

Institut za turizam. (2018). Stavovi i potrošnja turista u Hrvatskoj - TOMAS ljeto 2017. Zagreb: Institut za turizam.

Jeng, J. i Fesenmaier, D. R. (2002). Conceptualizing the Travel Decision-Making Hierarchy: A Review of Recent Developments, Tourism Analysis. 7(1), 15-32.

Kučiš, V., Plenković, M., Plenković, I. i Mustić, D. (2015). Basic conditions for successful business communication. Mario Plenković, Ludvik Toplak i Vlado Galičić (Ur.), Društvo i tehnologija 2015. - Dr. Juraj Plenković (str. 413422). Zagreb: Hrvatsko komunikološko društvo i Nonacom.

Kučiš, V. (2016). Translatologija u teoriji i praksi. Zagreb: Hrvatsko komunikološko društvo i Nonacom.

Lumsdon, L. (1997). Tourism Marketing. London: International Thomson Business Press.

Magaš, D., Vodeb, K. i Zadel, Z. (2018). Menadžment turističke organizacije $i$ destinacije. Opatija: Fakultet za menadžment u turizmu i ugostiteljstvu, Sveučilište u Rijeci.

Mihajlović, I. (2013). Dinamika utjecaja novih trendova u turizmu primjenom ICT-a i posljedice transformacijskih procesa na poslovanje turističkih agencija. Poslovna izvrsnost, 7(1): 45-71.

Ministarstvo turizma RH. (2017, 30. prosinca). Turizam u 2018. očekuje daljnji rast prometa, investicija i zapošljavanja. Dostupno na: https://mint.gov.hr/ vijesti/turizam-u-2018-ocekuje-daljnji-rast-prometa-investicija-i-zaposljavanja/11529.

Reuber, A. Rebecca i Fischer, E. (2011). International entrepreneurship in internetenabled markets. Journal of Business Venturing, 26(6): 660-679.

Saravanakumar, M. i Lakshmi, T. S. (2012). Social Media Marketing. Life Science Journal, 9(4): 4444-4451. 
Sheller, M. i Urry, J. (2004). Tourism Mobilities, Places to Places, Places in Play. London-New York: Routledge.

Standing, C., Tang-Taye J-P. i Boyer, M. (2014). The Impact of the Internet in Travel and Tourism: A Research Review 2001-2010. Journal of Travel \& Tourism Marketing, 31(1): 82-113.

Stein, W. Eric i Zwass, V. (1995). Actualizing organizational memory with information systems. Information Systems Research, 6(2): 85-117.

Ukpabi, D. C. i Karjaluoto, H. (2017). Consumers' acceptance of information and communications technology in tourism: A review. Telematics and Informatics. 34(5): 618-644.

Xiang, Z. i Gretzel, U. (2010). Role of social media in online travel information search. Tourism Management, 31(2): 179-188.

Zekanović-Korona, Lj. i Klarin, T. (2012). Internet: informacijsko-komunikacijska platforma za nove načine putovanja. Medijska istraživanja, 18(2): 59-72.

\section{INFLUENCE OF E-COMMUNICATION ON RAISING THE LEVEL OF EFFICIENCY OF THE CITY OF ZAGREB AS A TOURIST DESTINATION}

\section{Summary}

The purpose of this paper is to establish the importance of approach and representation of information and communication medium for tourist in Zagreb as a tourist destination, also whether and to which extent is such type of communication prevalent with respect to the direct communication with the tourist offer holders and citizens. As part of this paper, a quantitative research was carried out through a questionnaire given to tourists at Zagreb as the tourist destination, in the period between September 2017 to February 2018. The research included tourists who stayed in all city neighbourhoods being part of the tourist organisation of the City of Zagreb, and in total 202 questionnaires were filled out, of which 188 were filled out correctly. The subjects have, among other, assessed the awareness on existing destination contents, the possibility to communicate at the destination and the importance and representation of the information-communication medium. The results of the descriptive statistical analysis have shown that tourists gave a positive opinion on the awareness and possibility to communicate with the offer holders at the destination, while in the assessment of information-communication medium, the availability of Internet in accommodation facilities, restaurants and other food serving facilities as well as cafes and bars turned out to be the most important point. The results of the research have shown the necessity of further rethinking in order to define the communication opportunities offered by a certain destination and the introduction of innovations in the existing communication system.

Keywords: e-communication, tourist destination, social media, digitalisation 